\title{
時間および空間分解の測定法開発において考えてきたこと Things Coming Up to Mind during Development of Time- and Space-resolved Measurements
}

\author{
福村 裕史
}

Hiroshi Fukumura

\begin{abstract}
During the past 20 years, the author has made effort to expand the region of time- and space-resolved measurements to contribute to physical chemistry. Although his achievements are yet very far from his initially intended goals, the author describes the background of his ideas to begin new research subjects: 1) how fast liquid phase separation occurs; 2) availability of pulsed x-ray to time-resolved measurements; 3) possibility of sub-molecular spectroscopy for chemical reactions. Problems he faced and suggestions for improvements are also presented.
\end{abstract}

Keywords: phase separation dynamics, time-resolved x-ray diffraction, scanning tunneling microscopy

\section{1. はじめに}

物理化学は新しい測定法の開発と共に大きく進んできた。 実験を主とする物理化学の研究者は，それぞれの分野で新 しい測定法の開発に挑んでいると思う。光化学の分野でい えば，強いフラッシュランプを使って，反応の中間状態の スペクトルを直接に測定できるということを示したポーター (George Porter) 先生の業績は大きい1。極めて短い時間し か存在しないラジカルや励起状態の電子状態とその振る舞 いを調べられるようになって, 化学反応の理解はより深 まった。その後, 超短パルスレーザー技術の進歩に伴って, 時間分解測定法は大きく開花することになったが，基本的 な概念は今も変わっていない。ここでは約 20 年程度の間, 時間分解測定法の魅力にとりつかれて, 何とかこの領域を 拡大したいと努力を重ねた際に考えたことを記したい。ま た不均一系を扱う必要性から画像測定法あるいは空間分解 測定法にも関わらざるを得なかった。この辺の経緯も記し たい。

\section{2. 液体の相分離はどのぐらい早いのか}

この研究の起源は 1988 年にさかのぼる。当時, 京都工芸 纎維大学の教授であった増原宏先生に, 高分子固体のレー ザーアブレーションが起こるメカニズムの解明という課題 を頂いた ${ }^{2}$ 。各種の時間分解分光法を用いて調べた結果, 光 を吸収する分子がナノ秒のレーザーパルス幅内で何度も光 励起と無輻射失活を繰り返し, 高分子固体が急激に高温状 態になることが原因とわかった 3 。各種の形態変化測定法 も開発し，レーザーが照射された表面から物質の飛び出し が顕微鏡レベルで確認できるのは数 10 ナノ秒の時間スケー ルであることも明らかになった。レーザーアブレーション
の研究者の中には, 液体の突沸（explosive boiling）になぞ らえて相爆発 (phase explosion) と呼ぶ人もいた。そこで沸 き起こった疑問は，物質の相変化はどのぐらい早く起こる のかということである。それは自由エネルギーという概念 の枠組みの中で議論できるのだろうか。

この問題に答えるためには，試料として低分子の溶液を 用いるのが良いと考えた。高分子固体を用いる限り，レー ザー照射による物質の飛び出しは分子鎖の切断などの化学 反応を伴うため, 純粋に相変化の速さを反映しているとは 言い難い。さらに，できるだけ小さな温度ジャンプで相変 化が起きるのが望ましい。これらの条件を満たすものとし て, 室温付近では均一に混合し, 温度上昇により二相に分 離する溶液を選ぶことにした。トリエチルアミンやブトキ シエタノールは水と強い水素結合を作り室温付近では均一 相になるが，温度が上昇すると分離する。このような系の 相図を模式的に示すと Figure 1 のようになり下部臨界点を もつ。幸いにもこれらの低分子化合物は，隣接するアルキ ル基の炭素 - 水素伸縮振動の振動数が，水との水素結合に よって分子内電荷分布が変化するため高波数側にシフトす る (Figure 2) $)^{4,5}$ 。これを利用して，赤外パルスレーザーで 水を振動励起し溶液全体の温度を数ナノ秒で上昇させ，そ の後一定時間後に可視光パルスレーザーを用いてラマンス ペクトルを測定すれば, 水素結合している分子の割合が 時々刻々変化していく様子を調べることができる。このス ペクトル情報から，分子レベルで平衡状態に到達するまで には 1 マイクロ秒かかることがわかった (Figure 3) 6,7。こ れは各相の濃度変化に対応するので, Figure 1 の相図にお いて B 点より C および C' 点に到達するのにかかった時間 と考えても良い。この時間は相変化の速さとして早いと考 
えるべきなのか，遅いと考えるべきなのだろうか。

最初に述べたように，ナノ秒のパルスレーザー照射に よって固体や液体の表面から物質が飛び出すのは数 10 ナノ 秒と早い。したがって, 物質の飛び出しが起こる時間ス ケールでは分子の移動を伴うエントロピーは最大になって いるとは考えにくく，エンタルピー変化のみが寄与してい るであろう。自由エネルギーの概念そのものが適用できな い時間領域であり，エンタルピー爆発という方がふさわし い。ここで混同してならないのは, 物理学で扱うスピン格 子の相変化のような場合である。物質移動を伴わない相変 化においては, 極めて早いエントロピーの最大化が可能で

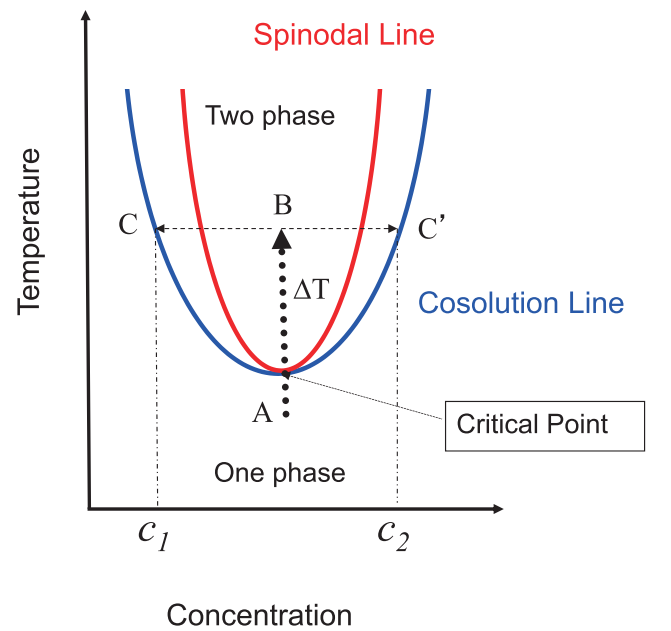

Figure 1. Typical phase diagram of a binary liquid mixture having a lower critical solution temperature. By a temperature rise, the mixture undergoes phase separation following the path from $\mathrm{A}$ to $\mathrm{C}$ and $\mathrm{C}^{\prime}$ through B.
あり，溶液の相分離とは挙動が異なる。

物質移動を伴うエントロピー変化が, 空間の大きさに応 じた時間を要する理由を簡単な例で説明しょう（Figure 4)。 一定の大きさの箱の中で, 熱運動している複数の球（黄色） を考える。この中央に置かれた 1 個の球（青色）は, 左右

(a)

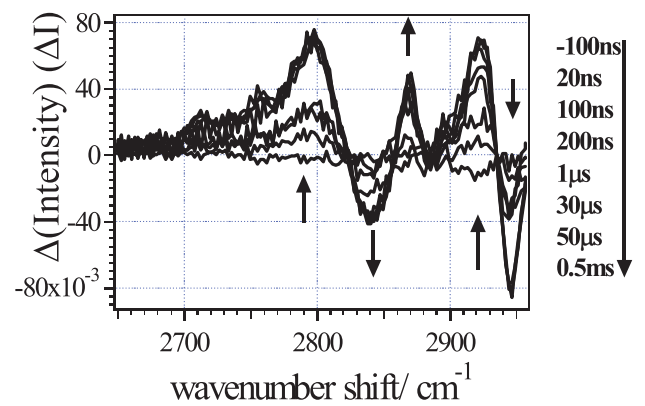

(b)

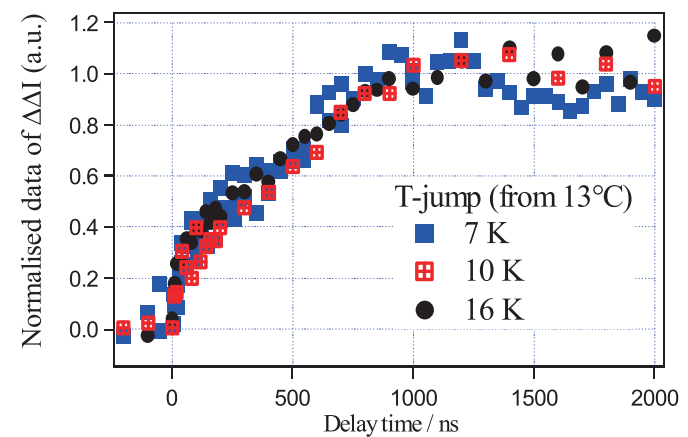

Figure 3. (a) Raman difference spectra for different delay times determined after the same laser induced T-jump above the critical temperature. (b) Normalized kinetics of molecular-level phase separation for different T-jumps from the initial temperature $(286 \mathrm{~K})$. Adapted with permission from J. Phys. Chem. B. ${ }^{6,7}$ Copyright 2003 American Chemical Society.
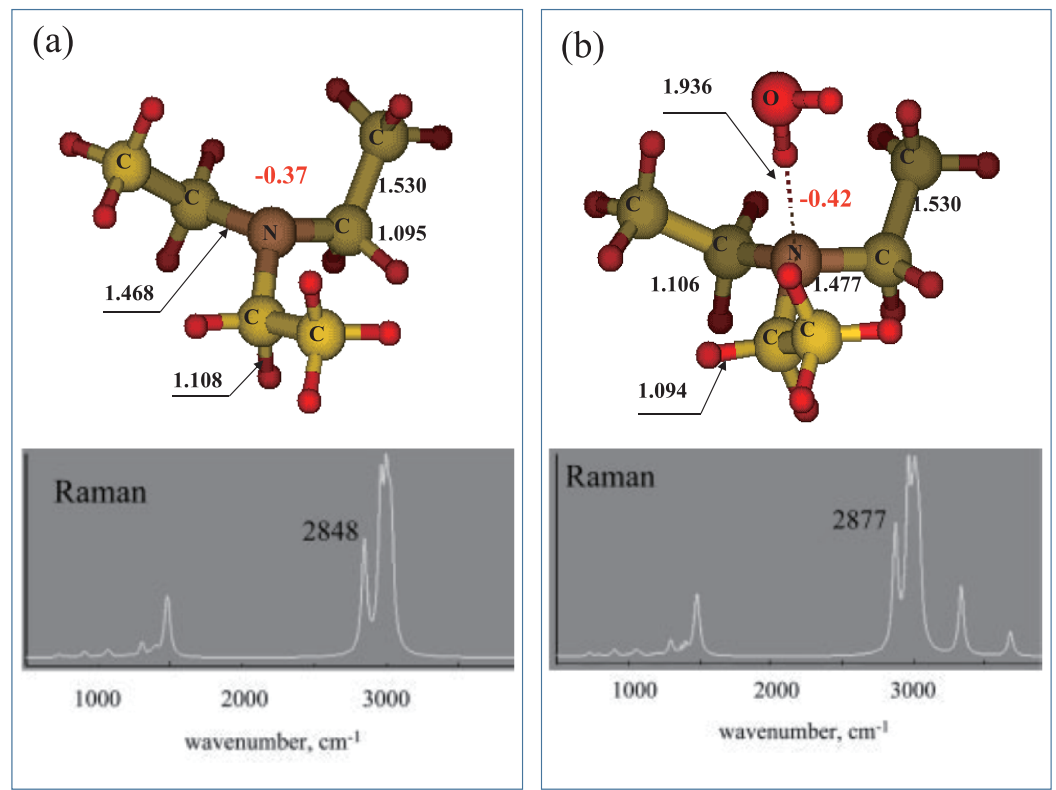

Figure 2. Calculated structures (top) and Raman spectra (bottom) of isolated triethylamine (a) and a triethylamine $/ \mathrm{H}_{2} \mathrm{O}$ complex (b). The selected bond distances (in $\AA$ ) and Mulliken charges on the $\mathrm{N}$ atom are also given in the top figures. The $\mathrm{C}-\mathrm{H}$ vibration at $2,877 \mathrm{~cm}^{-1}$ shifts to $2,848 \mathrm{~cm}^{-1}$ by phase separation owing to electron density changes in the triethylamine molecule. Adapted with permission from Intl. J. Quantum Chem. ${ }^{4,5}$ Copyright 2005 John Wiley and Sons. 
(a)

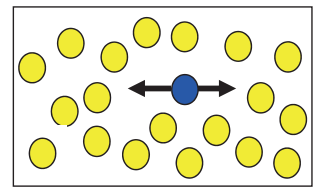

(b)

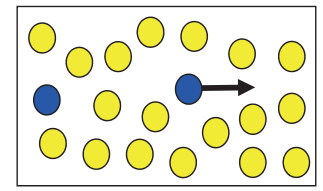

Figure 4. Simplified view to understand diffusion induced with entropy, where all coulombic force is ignored. (a) One blue ball should have the same probability for moving right and left by thermal fluctuation. (b) When one yellow ball is turned to blue at the left side in the same box, "chemical potential" induces the center blue ball to move right. Statistically two blue balls prefer separated, but there is no direct repulsive force between two balls. Thus, it takes a certain time for two balls to "feel" the potential depending on the size of box, the number of balls, and the thermal fluctuation degree.

どちらかに動く確率は同じはずである。ここで，球の間に はクーロンカなどの特別な相互作用は無いものと仮定する。 しかし，箱の左端にもう一個の青色球を置くと, 中央の青 色球は右に動く確率が増えるはずである。なぜならば, そ ちらの方がエントロピーは増えて, 化学ポテンシャルが小 さくなるからである。これは箱内の全ての球の配置を考え た時に，そちらの配置の方が場合の数が多いということに 過ざない。つまり純粋にエントロピーによる仮想的な力で ある。しかし，その仮想的な力が目に見えて働くためには， 球の配置について場合の数を全て試すだけの時間を要する。

化学ポテンシャルは物理化学の基本概念であり, ポテン シャルの微分を力と考えるのは当然である。しかし, 濃度 分布に伴う化学ポテンシャルから, あたかも高濃度側から 低濃度側に物質が流れるように力が働いていると考えるの は間違いである。このことについては, 光化学分野の亦引 者でもあったバーバラ (Paul Barbara) 先生が, 2005 年の八 ワイで開かれた学会で昖会いした時「化学ポテンシャルっ て奇妙（weird）だと思わないか」と話しかけてくれて少し 議論したことを思い出す。反応速度論に化学ポテンシャル を持ち込むときには, 空間サイズに応じたエントロピー最 大化のための時間を考慮しなければならない。いかに大き な濃度勾配でも, エントロピーによる仮想的力は空間の大 きさに支配されて時間がかかる。このように考えると，1 マイクロ秒という分子レベルの相変化の時間は, 対応する 大きさの空間で相平衡に達する時間と考えれば説明できる。 有機低分子の水中拡散定数から, 大雑把に $30 \mathrm{~nm}$ ぐらいの 空間の平衡化を見ていることになる。

上の議論では, 分子の配向変化や移動に伴ってエネル ギーが出入りしない不可逆過程を扱っている。実際の系で は, 拡散に伴ってクーロン力に起因するエネルギーの出入 りがあり，それに伴うエントロピー変化もあり得るので事

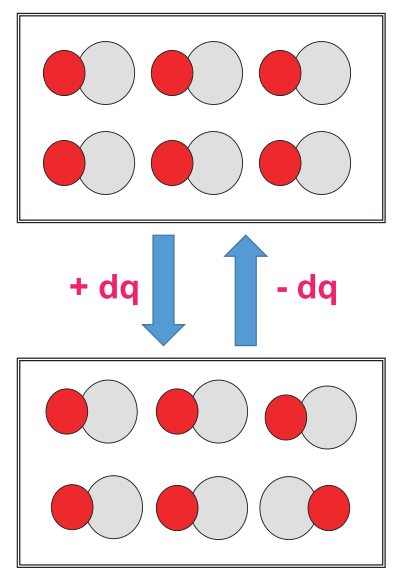

Figure 5. Imaginary crystal of heteronuclear diatomic molecules. Assuming that the total energy is lower at the top, one molecule can change the direction like at the bottom by adding a small amount of thermal energy, and the process is completely reversible, we can control the system's entropy only with heat transfer. Irreversible process occurs when thermal fluctuation changes the direction of molecules without heat transfer, meaning we can't control the order by heat transfer.

態は複雑である。ここでついでに，可逆過程を仮定できる 系では，出入りするエネルギー量を温度で割り算してエン トロピー変化が得られ, このような系のエントロピー変化 は不可逆過程においても同一の量として計算できることを 簡単に説明しておこう。Figure 5 に，異核二原子分子が同 じ方向に配向して並んでいる結晶を模式的に示す。もしこ こで，微小な熱エネルギーをこの系に与えることにより， 一個の分子の配向を逆向きに変えられるとしょう。このよ うな配向変化にはクーロンエネルギーの変化が伴うので, 当然エネルギーが必要である。逆に微小な同量の熱エネル ギーを系から奪うことにより，変化した分子の配向は元に 戻って整然と並ぶとすれば，これは可逆過程であり分子の 配向はエネルギーの出入りのみで制御できる。したがって 配向の変化に伴うエントロピー変化は, この微小量の熱の 出入りから計算できる。温度で割り算するのは, 系の持つ 乱雑さの平均值で規格化するためと考えれば良い。このよ うな系においても，出入りするエネルギーとエントロピー 変化の関係が不等号で表されるのは, エネルギーの出入り が無いにも関わらず，熱運動により分子が勝手に動いてし まうからである。これが不可逆過程である。もし仮に, 特 定の分子の配向と位置を熱エネルギーの出入りのみで制御 できて，熱運動による配向・位置の変化が起こらない系が あれば, 不可逆過程は存在しない。そのような完全な可逆 過程が考えられる場合にのみエントロピー変化は熱の出入 りから計算できるのであり，上で議論したクーロンエネル ギーの変化を伴わない拡散においては，エントロピーは増 えるが，その量は熱の出入りから計算できない。

もうひとつ相分離の速さを議論するとき話題になるのが スピノーダル分解によってできる構造である (Figure 6) ${ }^{8}$ 。 このような構造は, 高温で複数の金属が均一に融解混合し ていて上部臨界点を持つ系を，急激に冷却して相分離させ 


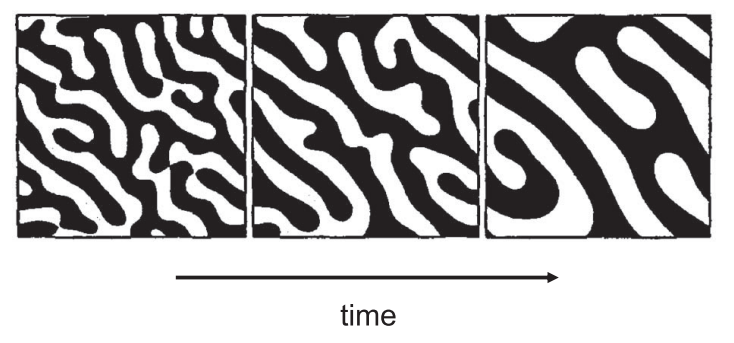

Figure 6. A typical example showing spinodal decomposition by computer simulation. The initial structure grows in size with time keeping the self-similarity. Adapted with the courtesy of Dr. Alexander Wagner from his Ph.D. thesis. ${ }^{8}$

た合金内部に見られる。同じことは下部臨界点を持つ系で も起こり, Figure 1 の臨界点（Critical Point）功左右に離 れた混合比において相図の共存線を少しだけ跨いで起こる 相変化は，系の内部にランダムに生成する核が成長するこ とによって起こる核生成モデルによって説明される。これ は相分離によって生ずる二つの相境界の界面エネルギーが 核の成長を妨げるからであり，熱摇らぎが界面エネルギー の効果を打ち消せるだけ大きければ核は突然成長するが, そのような大きな核が生成しない限り系は準安定状態にあ る。液体の突沸がみられるような状態と考えて良い。一方， このような混合溶液を低温から共存線を深く跨いで，二相 領域に急激に温度上昇させると, 界面エネルギーの効果は 小さくなり熱力学的に不安定な状態が空間に均一に生じる ことになる。これがスピノーダル分解とよばれる過程であ り，Figure 6 のような互いに連続した二相が絡まりあった 空間構造を与えることが連続体の計算機シミュレーション でも確認されている。実際に我々の扱った混合溶液でも, 数 10 マイクロ秒から数 100 マイクロ秒にかけての遅い時間 領域に扔いて, 溶液中にスピノーダル分解に特徽的な構造 が観測でき時間と共に成長している（Figure 7) 6,7。これは 連続体を仮定した相分離において, 後期段階（late stage） とよばれるドメイン成長に対応する。Figure 3 に示したよ うに，1 マイクロ秒では分子レベルで相平衡濃度に達して いるので，直ちにスピノーダル分解による特有の構造が出 来始めると仮定すれば，その空間周期は相成長の速度から 見積もって $70 \mathrm{~nm}$ ぐらいということになる。しかしながら， ごく最近, ナノ秒時間分解光散乱法によって, 空間周期構 造は数 $100 \mathrm{~nm}$ 以上もあり, しかもその空間周波数は 10 マ イクロ秒程度まで変化しないことが確認された 9 。つまり， 分子レベルでは平衡状態に既に達しているにもかかわらず， 連続体モデルで表される相分離の初期段階（early stage）は 1〜10 マイクロ秒で起こることになる。連続体モデルの初 期段階においては，スピノーダル分解により濃度が空間的 に均一に変化すると考えられているので，これらの実験結 果は矛盾している。では，1 マイクロ秒で生成した平衡状 態とはどのような状態であろうか。また連続体モデルの初 期段階で成長する相とはバルクの相とは違うのであろうか。 この部分の説明は，新しい概念を含んでいて大変重要なの (a)

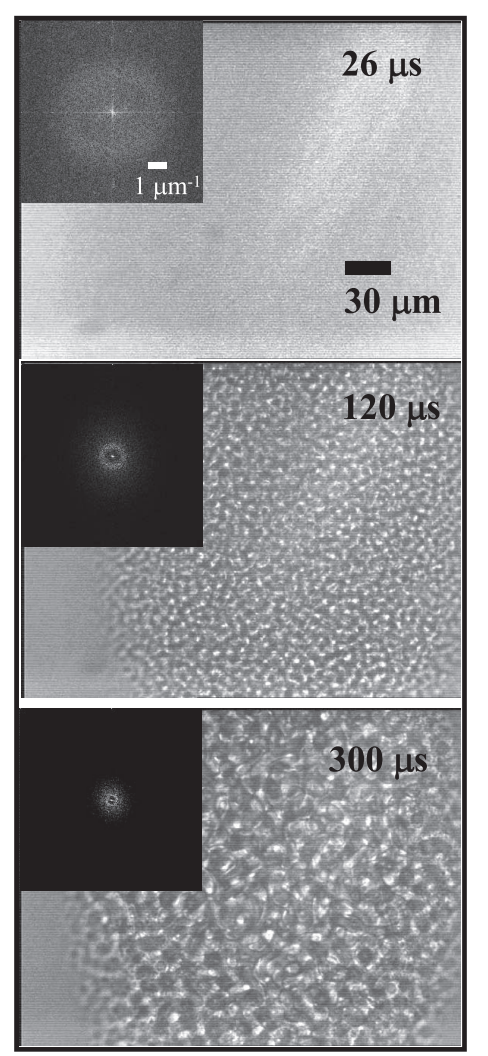

(b)

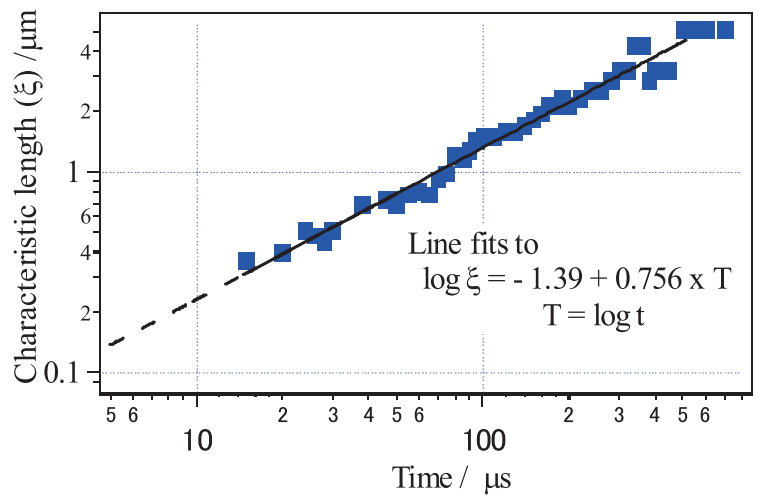

Figure 7. (a) Microscopic shadowgraphs and two-dimensional fast Fourier transforms taken at a temperature jump for phase separating triethylamine/water mixture. (b) Self-similar growth of phase domains at different times. Adapted with permission from J. Phys. Chem. B. ${ }^{6,7}$ Copyright 2003 American Chemical Society.

で別の機会に譲りたい10。

今後の研究は, 溶液中に漂って動いている柔らかいナノ 構造体を可視化することに向かうのではないだろうか。最 近，室温付近で均一に見える溶液でも，高温で相分離する 溶液中には不均一な凝集体が存在することが示唆された ${ }^{11}$ 。 Figure 8 に示すように，ミセル溶液では急速凍結割断一透 過型電子顕微鏡を用いて柔軟ナノ構造体の存在が確認され ているが 12 , これらの構造を常温の溶液中で実時間観測す る手法が近いうちに開発されることを期待している。この ような手法は, 細胞内微小構造体の働きを調べる際にも使 えるだろう。 


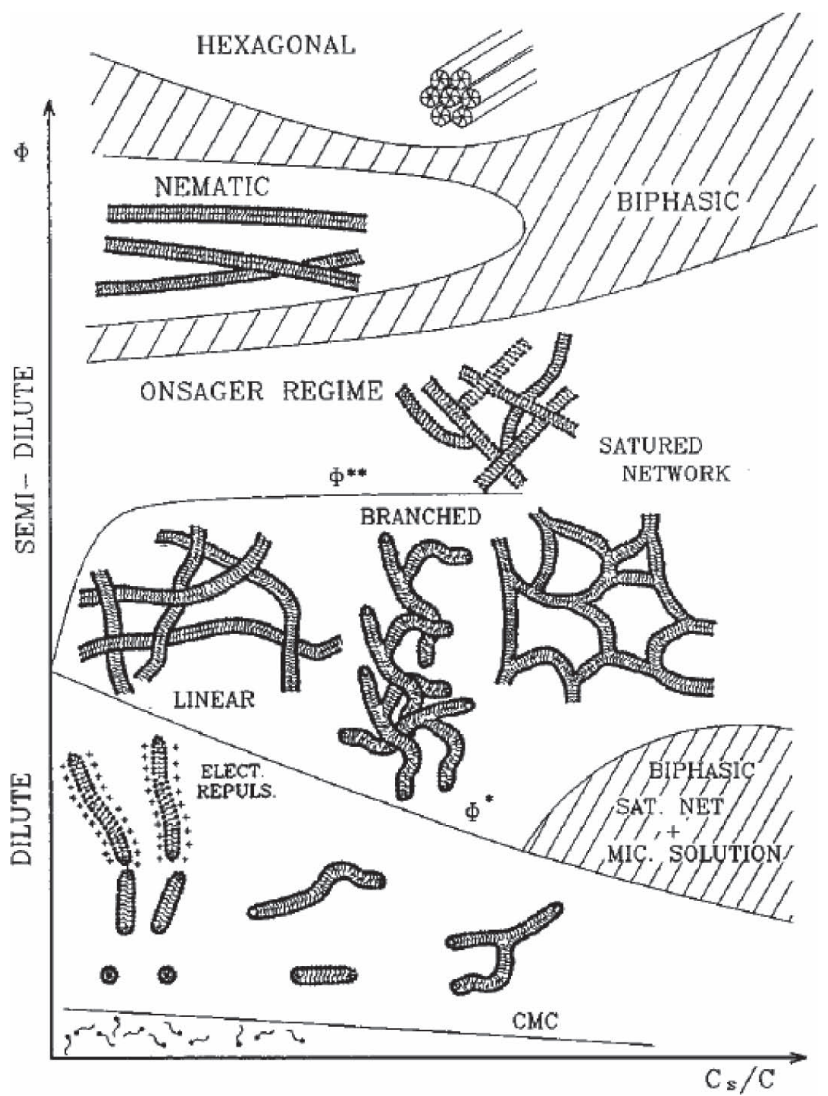

Figure 8. Schematic diagram of micellar morphologies. The ordinate represents the surfactant concentration and the abscissa salt molar ratio to surfactant. Reprinted with permission from Ref 12. Copyright 1998 American Chemical Society.

\section{3. レーザー誘起パルス X 線は時間分解構造解析に使 えないか}

パルスレーザーの技術的進歩は目を見張るものがあり， 今では容易に高出力のサブピコ秒レーザーが使えるように なった。紫外可視領域の時間分解分光法もこれによって飛 躍的に発展したと思うが, 観測する時間領域を単に短くす るだけでは無く，何か質的進歩に挑戦すべきと考えた。金 属や溶液に集光することで容易にX 線が発生することがわ かったので 13,14 , 時間分解 X 線回折も簡単にできるのでは ないかと予想したが落とし穴があった。失敗の理由は, X 線と紫外可視光では物質との相互作用の強さが大きく異な ることである。特に空気中で用いられる硬 $\mathrm{X}$ 線は物質との 相互作用が小さいので，人体などの透過像を撮影するのに 使われる。しかも回折は多数の原子からなる周期構造であ るので，局所的な変化を観察するのには向いていない。一 方，紫外可視光を使った分光法は，それを駆使している研 究者は気付いていないかもしれないが，とても恵まれてい ると思う。例えば, ラジカルカチオンなどのモル吸光係数 は 5 桁程度あるのが普通である。しかも元の光照射前の溶 液は吸収が無い波長領域に反応中間体の吸収スペクトルが 現われることが多い。したがって低濃度で微小な変化を検 出できる。ところが, 硬 X 線の場合には金属原子でもモル 吸光係数は 1 桁か 2 桁である。仮に共鳴しても散乱係数は
極めて小さいので，バルク全体の変化がないと検出は難し い。当然のことながら，バルク全体の変化を光で誘起する ためには多数の光子が必要であり，照射される試料は光で 損傷を受けることになる。高強度レーザーで繰り返し照射 しても損傷が起こらないためには, 光励起状態が化学反応 を起こさずに早く熱緩和し，かつ熱伝導度が高い試料でな くてはならない。結局，観測が容易なのは，金属など重た い原子からなる規則構造ということになる。このことに気 付くのに時間がかかりすぎた。

ようやく最近になって，金の薄膜結晶が測定しやすいこ とがわかってきたが，これは既に報告されていた ${ }^{15}$ 。金薄 膜の場合には，平滑な結晶表面をパルス光で励起した場合 でも，高エネルギーの電子が金属表面下で生成し，薄膜の 反対側に弾道電子の速さで到達することが知られている ${ }^{16}$ 。 ここで弾道電子とは，金属格子と衝突せずに金属内を移動 する電子で，その速さは電子のフェルミ速度と同じで $1.4 \times$ $10^{8} \mathrm{~cm} / \mathrm{s}$ （光速の $0.5 \%$ 程度）と見積もられている。つまり $300 \mathrm{~nm}$ 厚さの金の薄膜でも電子は 1 ピコ秒程度で裏側に到 達できる。金属格子との衝突で散乱された電子は格子に工 ネルギーを与えて，薄膜全体の格子の膨張が始まるが，こ れは金薄膜の厚さに依存し，150 nm の場合には立ち上がり に 60 ピコ秒はかかる。ところが，マイカ基板の上に金ナノ 粒子を蒸着し，この金ナノ粒子を紫外光で励起してマイカ 基板の格子振動を調べたところ，6ピコ秒で $1,700 \mathrm{~nm}$ 程度 の深さまでマイカ基板が澎張することが明らかとなった ${ }^{17}$ 。 この時間内に何かがエネルギーを伝達しているはずである が，その速さは $2.8 \times 10^{7} \mathrm{~cm} / \mathrm{s}$ であり，マイカの垂直方向の 音速 $5 \times 10^{5} \mathrm{~cm} / \mathrm{s}$ より桁外れに大きい。Figure 9 に用いた試 料とマイカの構造 ${ }^{18}$, 時間分解 X 線回折の結果を示す。面 白いことに，金ナノ粒子を平滑な基板に置き換えても，同 様なマイカ基板の膨張は観測できない。これは金薄膜内部 の高速弾道電子がマイカ基板との界面に衝突してもマイカ 基板には影響しないことを意味している。となると，金ナ ノ粒子のプラズモン励起がマイカ基板内部の電子を動かし ていることになる。このように速く固体内部を伝播するも のは, 弾道電子かバルクプラズモンぐらいしか考えられな い。絶縁体のバルクプラズモン励起には相当なエネルギー を要するが，十ノ粒子間のギャップモード励起による電場 変化が関与しているのであろう。

以上のように高出力・高繰返しパルスレーザーを用いれ ば，研究できる対象は限られているが，時間分解 X 線回折 やX 線吸収分光は可能と考えている。ここでもう一度, 我々の用いたレーザー装置は繰返しが $3 \mathrm{kHz}$ で，パルス 1 発のエネルギーが数 $100 \mu \mathrm{J}$ 程度であることを強調しておき たい。つまり，試料に損傷を与えない程度の弱い光で微小 な変化を引き起こし，これもまた弱いX線パルスを照射し て, 何 10 分と積算回数を稼いで回折像を得るのである。光 化学の分野では, かっては強いレーザーパルスで数回励起 
(a)

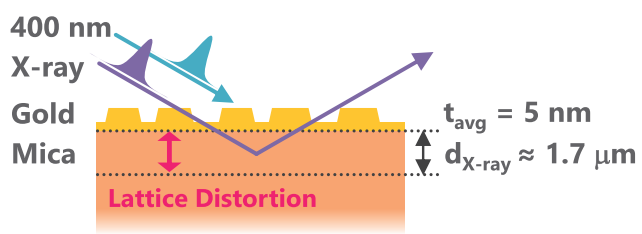

(b)

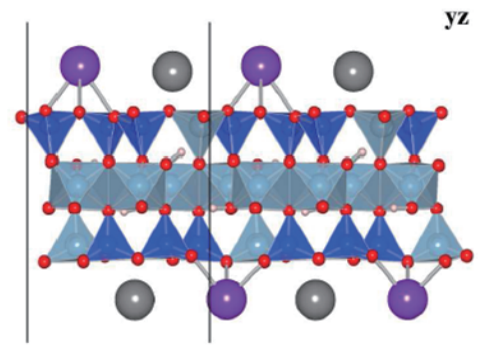

$\mathbf{K} \odot \mathbf{A l} \odot \mathbf{S i} \odot \mathbf{O} \bullet \mathbf{H}$ 。

(c)

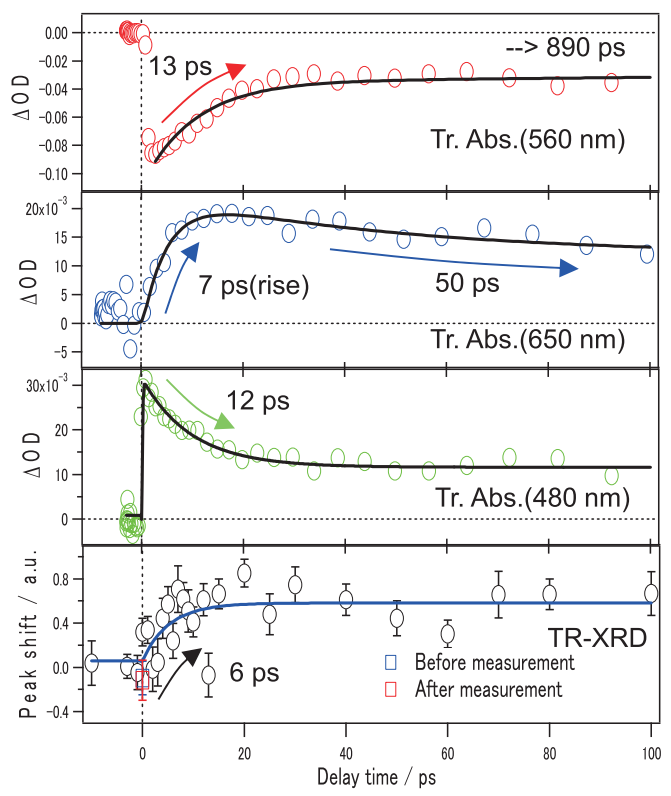

Figure 9. (a) Outline of the used sample and the employed pumpprobe method. Gold nanostructures are deposited by vacuum evaporation on mica and photo-excited with 400-nm sub-ps light pulse. The probe $\mathrm{x}$-ray pulse is from laser-induced plasma generated at the surface of metal iron. (b) Calculated structure for muscovite mica. Reprinted with permission from Ref. 18. Copyright 2011 by the American Physical Society. (c) Temporal profiles of absorbance changes by photo-excitation of gold nanostructures and the x-ray diffraction angles of the mica substrate. The mica expansion rise ( $c a .6 \mathrm{ps})$ detected with time-resolved $\mathrm{x}$-ray diffraction is faster than the decay of localized plasmon of gold nanostructures. Note that $\mathrm{x}$-ray penetrates to $1,700 \mathrm{~nm}$ in mica and $\mathrm{x}$-ray diffraction represents a rather thick layer. Adapted with permission from Ref. 17. Copyright 2015 The Chemical Society of Japan.

してデータを集めていたが，次第に，単一光子計数法によ り長い時間積算してデータを取る方が好まれるようになっ たと思う。光合成など, 現実に光で誘起される化学反応は, 強い光パルス照射で起こる現象とは異なるからである。だ から私自身は, さらに高繰返しのレーザーの出現に期待し ている。我々の取った方法論とは異なるが，レーザーのエ ネルギーが $15 \mathrm{~mJ}$, 繰返しが $20 \mathrm{~Hz}$ というレーザー装置を 用いて，プラズマ加熱用のレーザー波長を $800 \mathrm{~nm}$ から
$3,900 \mathrm{~nm}$ のより赤外にすると, 発生するパルス X 線の強度 が 25 倍になったという報告もある ${ }^{19}$ 。このような手法は, 高繰り返しレーザーにおいても有効かもしれない。

水などを用いたレーザー誘起プラズマからの X 線発光久 ペクトルは，熱制動輻射に起因するためボルッマン分布に したがい, むしろ軟 X 線領域で強い。また軟 X 線領域では, 前述したモル吸光係数が 2 桁から 3 桁に大きくなるので 20 , 測定系を真空にすることができれば，軟 X 線領域の分光に むしろ適しているのではないだろうか。軟X 線を用いた時 間分解分光法は，すでに金属のレーザーアブレーション研 究などに応用されてきた ${ }^{21}$ 。溶液をジェット状に真空中に 噴出することで, 溶液化学の研究にも軟 X 線分光は有用で あることが報告されている ${ }^{22}$ 。また，溶液試料を窒化珪素 のナノ薄膜で挟んで，真空中で測定する手法も有効である ことが示された ${ }^{23}$ 。テーブルトップのレーザーを用いて， 溶液内化学反応の軟 $\mathrm{X}$ 線時間分解分光が容易にできる時代 が訪れつつあると期待している。

\section{4. 分子の形を見ながら分光情報は得られないか}

固体や液体にレーザーを照射して起こる変化をスペクト ル情報のみから研究していると, そのスペクトルが形態変 化する前の状態のものであるのか，形態変化後のものであ るのかが気になる。単純に形態や屈折率などの物理的変化 のため, 波長によって異なる光散乱が起こり見かけのスペ クトル変化を引き起こす場合もある。最近のレーザーは容 易に高出力が得られるので注意が必要である。試料の微小 な形態変化を容易に観測するためには，顕微鏡を用いるの が容易である。このためレーザーアブレーションの研究に おいても，顕微鏡下でレーザー照射を行うことが多くなっ た。同じ頃，単一分子を観測する研究者も光学顕微鏡を用 いていたが, 彼らの研究はナノメートルの分解能が得られ る超解像光学顕微鏡の開発につながった。今や, ナノ構造 体を一個一個見ながらスペクトルを観測するのが当たり前 になって来た。単一分子分光を超える空間分解分光法は, 走査型トンネル顕微鏡を用いたサブ分子分光法あるいは分 子内局所分光法であろう。極低温の高真空下でこれはすで に実現していて，最近では励起状態のダイナミクスまで調 べられるようになった ${ }^{24,25}$ 。これらの研究は, 分子の励起 状態の持つ素過程を確実に明らかにして行くであろう。し かし個人的には，化学は溶液内反応を扱うところに面白み があると考えているので，常温の溶液内とか固液界面でこ そ実現して欲しいと考えている。

今になってみれば珍しくもないが, 最初に固液界面に吸 着したピレン誘導体の形が常温で見えたときには本当に感 動した (Figure 10 ${ }^{26}$ 。孤立したピレン分子の芳香環が円環 状に見え，長いアルキル基がジグザグの鎖に見える。これ まではNMR などを用いて分子の形を間接的に観測してい たのに，直接見える時代になった。しかも常温の固液界面 

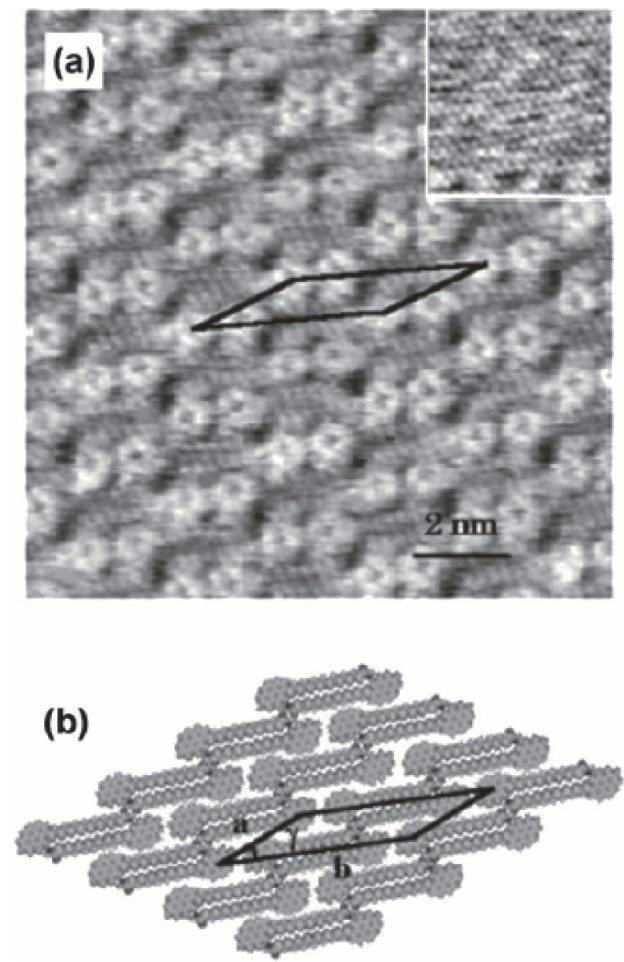

Figure 10. (a) An STM image of 1-pyrenehexadecanoic acid on HOPG. The inset is an STM image of the underlying graphite substrate. (b) Space-filling model of 1-pyrenehexadecanoic acid. The number of molecules per unit cell is two. Reproduced from Ref. 26 with permission from the PCCP Owner Societies.
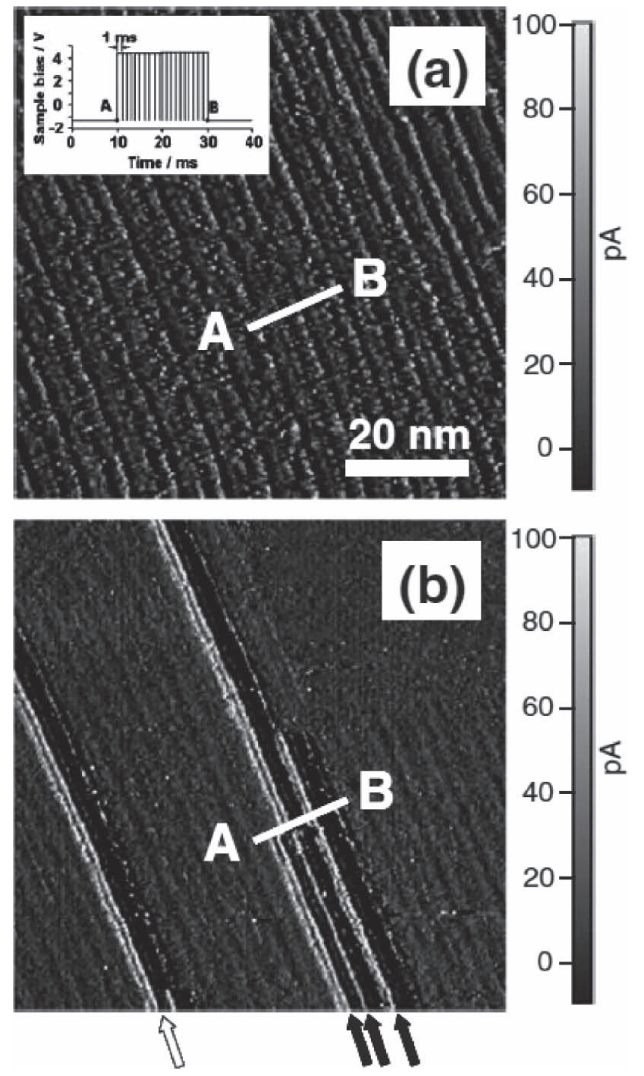

Figure 11. STM images in an $80 \mathrm{~nm} \times 80 \mathrm{~nm}$ area of the monolayer before (a) and immediately after (b) applying a pulsed voltage of $4 \mathrm{~V}$. Black and white arrows indicate portions where the polymerization reaction occurred beneath and $30 \mathrm{~nm}$ away from the tip respectively. The inset shows the pulsed voltage profile applied along the line $\mathrm{AB} .^{27}$ Copyright 2005 The Japan Society of Applied Physics.
では分子の吸脱着や配向変化も可能なので，化学反応に よって分子の形が変わることもモニターできる（Figure 11) ${ }^{27}$ 。しかし，未だこれらの分子のスペクトルをそのまま 選択的に測定することはできていない。現状では，ギャッ プモードプラズモンを用いた走査型トンネル顕微鏡が近道 のように見えるが 28 , 透過型や走査型の電子顕微鏡や軟 X 線顕微鏡の応用も考えられる。前述したように，窒化珪素 のようなナノ薄膜でシールすれば，溶液試料も真空中に持 ち込むことができるからである 23 。当面はニアフィールド の手法が優勢に見えるが, ファーフィールドの測定法も進 んで来るのではないだろうか。

\section{5. おわりに}

「想像できることは実現できる」という言葉を信じている 科学者は多い。こんなことができたらいいなという夢は, 常識を破る形で実現してきたように感じている。全てがわ かって研究することが無くなってしまわないかと不安にも なったりするが, 不思議なもので新しい研究対象, 新しい 手法, 新しい疑問は次々と出てくるものである。これから は生きている細胞内の働き, 脳機能の研究など, 生命関連 分野に物理化学に関連した新しい手法がつぎ込まれて行く だろう。また我々の体をランダムに通過している素粒子や 電磁波が, 自然の物理変化や化学変化に関与しているかも しれない。物理化学者のだれかの夢が，いつの日か予想も つかない方法で実現できるのではないかと期待している。

無謀なことばかり挑戦して, 回りの方々, 特に学生の皆さんに は迷惑をかけたと反省している。このような研究を続けられたのは, 支えてくれるスタッフが居たからでもある。畑中耕治, Jonathan Hobley, Nurbosyn Zhanpeisov, 西尾悟 (故人), 梶本慎二, 堀本訓 子, 柴田穣の各氏に深く感謝したい。

\section{参考文献}

(1) Porter, G. Flash photolysis and some of its applications, Nobel Lecture, Dec. 11, 1967 (https://www.nobelprize.org/nobel_prizes/ chemistry/laureates/).

（2）増原 宏，板谷 明，福村裕史，高分子 1989, 38, 832 .

(3) Fukumura, H.; Hatanaka, K.; Hobley, J. J. Photochem. Photobiol. C: Reviews 2001, 2, 153-167.

(4) Zhanpeisov, N. U.; Ohta, K.; Kajimoto, S.; Hobley, J.; Hatanaka, K.; Fukumura, H. Intl. J. Quantum Chem. 2005, 105, 376-386.

(5) Zhanpeisov, N. U.; Takanashi, S.; Kajimoto, S.; Fukumura, H. Chem. Phys. Lett. 2010, 491, 151-155.

(6) Hobley, J.; Kajimoto, S.; Takamizawa, A.; Ohta, K.; Tran-Cong, Q.; Fukumura, H. J. Phys. Chem. B 2003, 107, 11411-11418

(7) Takamizawa, A.; Kajimoto, S.; Hobley, J.; Fukumura, H.; TranCong, Q. Phys. Rev. E 2003, 68, 020501.

(8) Wagner, A. Theory and applications of the lattice Boltzmann method, PhD Thesis, Univ. Oxford, 1997, p. 15.

(9) Toyouchi, S.; Kajimoto, S.; Toda, M.; Kawakatsu, T.; Akama, Y.; Kotani, M.; Fukumura, H. Chem. Lett. 2014, 43, 1838-1840. 
(10) Toyouchi, S.; Kajimoto, S.; Toda, M.; Kawakatsu, T.; Akama, Y.; Kotani, M.; Fukumura, H. to be published.

(11) Toyouchi, S.; Kajimoto, S.; Barzan, D.; Kiel, A.; Enderlein, J.; Fukumura, H.; Herten, D.-P. ChemPhysChem 2014, 15, $3832-$ 3838.

(12) Magid, L. J. J. Phys. Chem. B 1998, 102, 4064-4074.

(13) Hatanaka, K.; Miura, T.; Fukumura, H.; Appl. Phys. Sci. 2002, 80, 3925-3927.

(14) Hatanaka, K.; Yomogihata, K.; Ono, H.; Fukumura, H. Appl. Surf. Sci. 2005, 247, 232-237.

(15) Chen, J.; Chen, W.-K.; Tang, J.; Rentzepis, M. Proc. Natl. Sci. USA 2011, 108, 18887-188892.

(16) Brorson, S. D.; Fujimoto, J. G.; Ippen, E. P. Phys. Rev. Lett. 1987, 59, $1962-1965$.

(17) Sotome, H.; Azuma, Y.; Asami, S.; Matsushima, S.; Kajimoto, S.; Fukumura, H. Chem. Lett. 2015, 44, 961-963.

(18) Rudenko, A. N.; Keil, F. J.; Katsnelson, M. I.; Lichtenstein, A. I. Phys. Rev. B 2011, 83, 045409.

(19) Weisshaupt, J.; Juvé, V.; Holtz, M.; Ku, S. A.; Woerner, M.; Elsaesser, T.; Ališauskas, S.; Pugžlys, A.; Baltuškanature, A. Nature Photonics 2014, 8, 927-930.
(20) Henke, B. L.; Gullikson, E. M.; Davis, J. C. Atomic Data Nuclear Data Tables 1993, 54, 181-342.

(21) Oguri, K.; Okano, Y.; Nishikawa, T.; Nakano, H. Phys. Rev. B 2009, 79, 144106.

(22) Lange, K. M.; Kotheab, A.; Aziz, E. F. Phys. Chem. Chem. Phys. 2012, 14, 5331-5338.

(23) Schreck, S.; Gavrila, G.; Weniger, C.; Wernet, P. Rev. Sci. Instrum. 2011, 82, 103101.

(24) Imada, H.; Miwa, K.; Imai-Imada, M.; Kawahara, S.; Kimura, K.; Kim, Y. Nature 2016, 538, 364-367.

(25) Cocker, T. L.; Peller, D.; Yu, P.; Repp, J.; Huber, R. Nature 2016, 539, 263-267.

(26) Uji-i, H; Yoshidome, M.; Hobley, J.; Hatanaka, K.; Fukumura, H. Phys. Chem. Chem. Phys. 2003, 5, 4231-4235.

(27) Nishio, S.; I-I, D.; Matsuda, H.; Yoshidome, M.; Uji-i, H.; Fukumura, H. Jpn. J. Appl. Phys. 2005, 44, 5417-5420.

(28) Horimoto, N. N.; Tomizawa, S.; Fujita, Y.; Kajimoto, S.; Fukumura, H. Chem. Commun. 2014, 50, 9862-9864.

（受理日 2017 年 8 月 5 日）

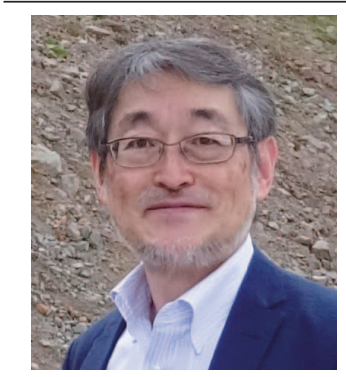

福村 裕史（ふくむら ひろし）

所属: 仙台高等専門学校・校長 理学博士 東北大学名誉教授

専門分野: 物理化学, 光化学

連絡先：干 989-3128 仙台市青葉区愛子中央 4-16-1 仙台高等専門学校・広瀬キャンパス

電子メール : fukumura@sendai-nct.ac.jp

URL : http://www.sendai-nct.ac.jp/english/cg/message.html 